\title{
A DIVULGAÇÃO DE PESQUISAS COM SERES HUMANOS NOS PERIÓDICOS DE ENFERMAGEM: QUESTÕES ÉTICAS
}

Maria Helena Palucci Marziale ${ }^{1}$

Isabel Amélia Costa Mendes ${ }^{2}$

Atualmente a mídia vêm explorando questões éticas de pesquisas sobre testagem de medicamentos, transplante de órgãos, estudos do código genético e clonagens. No entanto, a preocupação com os aspectos éticos das pesquisas com seres humanos ficaram evidentes desde a década de 40, devido aos crimes de guerra ocorridos durante a Segunda Guerra Mundial. Em 1947, foi então elaborado o código de Nuremberg ${ }^{(1)}$ onde foram estabelecidos vários tópicos a serem seguidos quando da realização de experimentos envolvendo seres humanos com vistas à salvaguardar a dignidade humana.

A partir da Declaração de Helsinque ${ }^{(2)}$ datada de 1964 , os protocolos de pesquisas com seres humanos passaram a ser analisados por Comitê independente do investigador e os relatos de experimentos fora dos princípios desta Declaração passaram a não ser aceitos para publicação.

No Brasil, somente a partir da década de 80 começaram surgir exigências quanto ao consentimento e a necessidade de aprovação e acompanhamento de protocolos de pesquisas com seres humanos. Em 1988, o Conselho Nacional de Saúde do Ministério da Saúde ${ }^{(3)}$ estabelece a necessidade do consentimento pós-informação e aprovação de projetos de pesquisa por Comitê de Ética, os quais foram mantidos nas recomendações da Resolução 196/96 $6^{(4)}$, através da qual vários conceitos de bioética em pesquisa com seres humanos foram incorporados, sendo estabelecido também a necessidade de tornar público os resultados das pesquisas.

Diante das recomendações internacionais e nacionais, os periódicos científicos, veículos de divulgação dos resultados dessas pesquisas e do conhecimento científico produzido, podem contribuir para a melhoria da qualidade não apenas técnica do artigo, mas também sobre preservação das questões éticas. No entanto, em estudo publicado em 1999, sobre a análise das instruções aos autores de 139 revistas cientificas brasileiras, os pesquisadores ${ }^{(5)}$ concluíram que na maioria das revistas brasileiras há pouca preocupação em relação aos aspectos éticos das pesquisas envolvendo seres humanos, inclusive nos periódicos de enfermagem.

Tais resultados, nos chamaram a atenção, pois temos conhecimento de que muitos editores de revistas de enfermagem estão atentos a essas questões, no entanto seria prudente uma revisão nas instruções aos autores quanto a obrigatoriedade da apresentação do protocolo de aprovação da pesquisa envolvendo seres humanos por Comitê de ética e do termo de consentimento emitido pelos sujeitos. Salientamos ainda, que é esperado dos autores a preservação dos valores humanos essenciais, pois o pesquisador além da competência técnico-científica, deve possuir conhecimentos de bioética.

\section{REFERÊNCIAS BIBLIOGRÁFICAS}

1. Vollmann J, Winau R. Informed consent in human experimentation before the Nuremberg Code. BMJ 1996 Dec; 313(7070): 1445-9.

2. World Medical Association Declaration of Helsinki. Recomm endations guiding physicians in biomedical research involving human subjects. JAMA 1997 Mar; 277:925-6.

3. Ministério da Saúde (BR). Conselho Nacional de Saúde. Normas de pesquisa em saúde. Resolução 01. 1998. Brasília:CNS; 1998.

4. Ministério da Saúde (BR). Conselho Nacional de Saúde. Diretrizes e normas regulamentadoras sobre pesquisa envolvendo seres humanos. Resolução 196. 1996. Brasília: CNS; 1996.

5. Sardenberg T, Muller SS, Pereira HR, Oliveira RA, Hossne WS. Análise dos aspectos éticos da pesquisa em seres humanos contidos nas instruções aos autores de 139 revistas científicas brasileiras. Rev Assoc Méd Bras 1999 dez; 45:295-302.

Editores da Revista Latino-Americana de Enfermagem da Escola de Enfermagem de Ribeirão Preto da Universidade de São Paulo, Centro Colaborador da OMS para o desenvolvimento da pesquisa em enfermagem: ${ }^{1}$ Professor Livre-Docente, e-mail: marziale@eerp.usp.br; ${ }^{2}$ Professor Titular, e-mail: iamendes@eerp.usp.br 


\section{THE PUBLICATION OF STUDIES INVOLVING HUMAN EXPERIMENTATION IN NURSING JOURNALS: ETHICAL ISSUES}

Maria Helena Palucci Marziale ${ }^{1}$

Isabel Amélia Costa Mendes ${ }^{2}$

Nowadays, the communication media have been exploring ethical issues concerning research on medication testing, organ transplantation, the genetic code and cloning. However, the concern about the ethical aspects of research involving human experimentation became evident in the 1940s due to war crimes occurring during World War II. As a result, the Nuremberg Code ${ }^{(1)}$ was elaborated in which various topics to be followed during the conduction of experiments with human beings were established in order to protect human dignity.

After the Declaration of Helsinki ${ }^{(2)}$, dated 1964, the protocols of research involving human experimentation started to be analyzed by the investigator's independent Committee and experiments that were not in accordance with the principles in that Declaration were not accepted for publication.

In Brazil, it was only in the 1980s that such requirements began to appear concerning consent and the need for approval and followup of protocols for research involving human experimentation. In 1988, The National Health Council of the Health Ministry ${ }^{(3)}$ established the requirement of post-information consent and the approval of research projects by ethics committees, maintained in the recommendations set forth by Resolution 196/96 ${ }^{(4)}$ and through which various concepts concerning bioethics in research with human experimentation were incorporated and the need to make research results public was also established.

In face of national and international recommendations, scientific journals, the vehicles of dissemination for the results of such research as well as of scientific knowledge, can contribute to the improvement of not only articles' technical quality, but also to the preservation of ethical issues. However, in a study published in 1999 on the analysis of guidelines for authors in 139 Brazilian scientific journals, researchers ${ }^{(5)}$ concluded that in most of the Brazilian journals, there is little concern with regard to the ethical aspects of research involving human experimentation, including nursing journals.

Such results called our attention since we are aware of the fact that many nursing journal editors have been attentive to these issues; however, a review of the guidelines for authors would be prudent so as to evaluate the requirement of an approval protocol for research involving human experimentation to be presented by an Ethics Committee as well as the Informed Consent to be provided by the subjects. We point out that authors are expected to preserve essential human values since, in addition to technical and scientific competence, researchers must also have knowledge on bioethics.

\section{REFERENCES}

1. Vollmann J, Winau R. Informed consent in human experimentation before the Nuremberg Code. BMJ 1996 Dec; 313(7070): 1445-9.

2. World Medical Association Declaration of Helsinki. Recomm endations guiding physicians in biomedical research involving human subjects. JAMA 1997 Mar; 277:925-6.

3. Ministério da Saúde (BR). Conselho Nacional de Saúde. Normas de pesquisa em saúde. Resolução 01. 1998. Brasília:CNS; 1998.

4. Ministério da Saúde (BR). Conselho Nacional de Saúde. Diretrizes e normas regulamentadoras sobre pesquisa envolvendo seres humanos. Resolução 196. 1996. Brasília: CNS; 1996.

5. Sardenberg T, Muller SS, Pereira HR, Oliveira RA, Hossne WS. Análise dos aspectos éticos da pesquisa em seres humanos contidos nas instruções aos autores de 139 revistas cientificas brasileiras. Rev Assoc Méd Bras 1999 dez; 45:295-302.

Editors of Latin American Journal of Nursing of Ribeirão Preto of the University of São Paulo at Ribeirão Preto College of Nursing - WHO Collaborating Centre for Nursing Research Development: ${ }^{1}$ Associate Professor, e-mail: marziale@eerp.usp.br; ${ }^{2}$ Full Professor, e-mail: iamendes@eerp.usp.br 


\section{LA DIVULGACIÓN DE INVESTIGACIONES CON SERES HUMANOS EN LAS REVISTAS DE ENFERMERÍA: CUESTIONES ÉTICAS}

Maria Helena Palucci Marziale ${ }^{1}$

Isabel Amélia Costa Mendes ${ }^{2}$

Actualmente los medios masivos de comunicación vienen explotando cuestiones éticas de investigaciones sobre pruebas de medicamentos, transplante de órganos, estudio del código genético y clonajes. Aún así, la preocupación con los aspectos éticos de las investigaciones con seres humanos son evidentes desde la década de los años 40 , debido a los crímenes de guerra ocurridos durante la segunda guerra mundial. En 1947 se elaboró el Código de Nuremberg ${ }^{(1)}$ en donde fueron establecidos varios tópicos para ser seguidos cuando se realicen experimentos comprometiendo seres humanos con miras a salvaguardar la dignidad humana.

A partir de la Declaración de Helsinki ${ }^{(2)}$ realizada en 1964, los protocolos de investigaciones con seres humanos pasaron a ser analizados por un Comité independiente del investigador y los relatos de experimentos fuera de los principios de esta declaración pasaron a no ser aceptados para publicación.

En el Brasil, solamente a partir de la década de los años 80 comenzaron a surgir exigencias relacionadas con el consentimiento y la necesidad de aprobación y acompañamiento de protocolos de investigación con seres humanos. En 1988, el Consejo Nacional de Salud, del Ministerio de Salud ${ }^{(3)}$ establece la necesidad del consentimiento informado y la aprobación de proyectos de investigación por parte de los Comités de Ética, los cuales fueron mantenidos en las recomendaciones de la Resolución 196/96 ${ }^{(4)}$, a través de la cual varios conceptos de Bioética en investigación con seres humanos fueron incorporados, estableciéndose también la necesidad de convertir en públicos los resultados de las investigaciones.

Frente a las recomendaciones internacionales y nacionales, las revistas científicas, órganos de divulgación de los resultados de esas investigaciones y del conocimiento científico producido, pueden contribuir con el mejoramiento de la calidad no solo técnica del articulo, ci no también con la preservación de las cuestiones éticas. Aun así, en un estudio publicado en 1999, sobre el análisis de las instrucciones a los autores de 139 revistas científicas brasileñas, los investigadores ${ }^{(5)}$ concluyeron que en la mayoría de las revistas brasileñas hay poca preocupación en relación con los aspectos éticos de la investigaciones que envuelven seres humanos, inclusive en las revistas de enfermería.

Tales resultados nos llamaron la atención, pues tenemos conocimiento de que muchos editores de revistas de enfermería están atentos a esas cuestiones, aun así, seria prudente una revisión de las instrucciones a los autores en relación con la obligatoriedad de la presentación del protocolo de aprobación de la investigación envolviendo seres humanos por parte de un Comité de Ética y del termino de consentimiento emitido por los sujetos. Resaltamos que se espera de los autores la preservación de los valores humanos esenciales, pues el investigador además de la competencia técnico-cientifica, debe poseer conocimientos de Bioética.

\section{REFERENCIAS BIBLIOGRÁFICAS}

1. Vollmann J, Winau R. Informed consent in human experimentation before the Nuremberg Code. BMJ 1996 Dec; 313(7070): 1445-9.

2. World Medical Association Declaration of Helsinki. Recomm endations guiding physicians in biomedical research involving human subjects. JAMA 1997 Mar; 277:925-6.

3. Ministério da Saúde (BR). Conselho Nacional de Saúde. Normas de pesquisa em saúde. Resolução 01. 1998. Brasília:CNS; 1998.

4. Ministério da Saúde (BR). Conselho Nacional de Saúde. Diretrizes e normas regulamentadoras sobre pesquisa envolvendo seres humanos. Resolução 196. 1996. Brasília: CNS; 1996.

5. Sardenberg T, Muller SS, Pereira HR, Oliveira RA, Hossne WS. Análise dos aspectos éticos da pesquisa em seres humanos contidos nas instruções aos autores de 139 revistas científicas brasileiras. Rev Assoc Méd Bras 1999 dez; 45:295-302.

Editores de la Revista Latinoamericana de Enfermería de la Escuela de Enfermería de Ribeirão Preto de la Universidad de São Paulo, Centro Colaborador de la OMS para el desarrollo de la investigación en enfermería: ${ }^{1}$ Profesor Libre-Docente, correo electrónico: marziale@eerp.usp.br; ${ }^{2}$ Profesor Titular, correo electrónico: iamendes@eerp.usp.br 